\title{
DA ESTRATÉGIA CORPORATIVA À AÇÃO ECONOMICAMENTE RELEVANTE: A CSN E A CONTESTAÇÃO SOCIAL NA MINERAÇÃO DE FERRO'
}

\section{FROM CORPORATE STRATEGY TO ECONOMICALLY RELEVANT ACTION: THE CSN AND SOCIAL CONTESTATION IN IRON ORE MINING}

\author{
Rodrigo Salles Pereira dos Santos*
}

Quando a coisa é pra todo mundo, que é um bem que você necessita para sobreviver, o povo junta. Que é a água!

\section{Introdução}

Este trabalho tem como objetivo estabelecer algumas considerações teórico-metodológicas preliminares acerca das relações entre economia, política e sociedade, operacionalizando a tipologia weberiana das formas de ação social (WEBER, 2000). Primeiramente, assume a centralidade da ação econômica derivada da capacidade transformadora ou desenvolvimentista de grandes projetos de investimento (GPIs) (VAINER, 1989). Por sua vez, põe em pé de igualdade a emergência de formas sociopolíticas (RAMALHO, 2005) de reação que operam em um gradiente de contestação social (HOMMEL e GODARD, 2005), potencialmente capaz de conduzir ao confronto político (TILLY e TARROW, 2007). Entende-se aqui que tais formas de (re)ação são economicamente relevantes, à medida que influenciam, em graus variados, estratégias privadas e públicas de desenvolvimento econômico.

\footnotetext{
* É Doutor em Ciências Humanas (Sociologia) e Professor Adjunto da Universidade Federal do Rio de Janeiro (UFRJ/Rio de Janeiro/RJ/Brasil). Atua na Sociologia Econômica, com foco em desenvolvimento, redes globais de produção e mineração de ferro. santosrodrigosp@hotmail.com.

1. Este artigo é uma versão ligeiramente modificada e atualizada de trabalho publicado nos Anais do 37॰ Encontro Anual da ANPOCS, 2013, em coautoria com o Prof. Dr. Raphael Jonathas da Costa Lima (UFF), a quem registro meu agradecimento. A pesquisa na qual se apoia obteve financiamento da Fundação de Amparo à Pesquisa do Estado do Rio de Janeiro (FAPERJ), por meio dos editais de Apoio ao Desenvolvimento Científico e Tecnológico Regional (DCTR) 2012 e Auxílio Instalação (INST) 2013/2. 0 autor agradece também os comentários de dois pareceristas anônimos.
}

2. Líderança comunitária do Pires 1, 2012. 
Como estudo de caso, o trabalho apresenta um conjunto de estratégias empresariais e estatais promotoras de desenvolvimento econômico, assim como formas reativas e conflitivas (contestação e confronto) postas em prática por agentes sociais diversificados no município de Congonhas (MG), onde operam a Companhia Siderúrgica $\mathrm{Na}$ cional S.A. (CSN) e a Nacional Minérios S.A. (Namisa), além de outras três mineradoras (Ferrous Resources do Brasil Ltda., Ferro Mais Mineração Ltda. e Vale S.A.). Nos últimos anos, este município vem sendo palco de uma disputa que coloca em lados opostos estratégias de intensificação da atividade de mineração por certos agentes econômicos e a reação de agentes sociais opositores. Em grande medida, sua posição antagônica remete ao risco potencial de tais estratégias à preservação da Serra Casa de Pedra, aqui entendida como significativa em duas dimensões: material, por conta dos pontos de captação de água que compreende; e simbólica, em função de reunir um importante conjunto escultórico, reconhecido pela Organização das Nações Unidas para a Educação, a Ciência e a Cultura (UNESCO) como Patrimônio Cultural da Humanidade desde 1985. A Serra é o principal elemento em disputa no debate que cerca a ampliação da mineração em Congonhas, particularmente pela CSN.

Assim sendo, o artigo começa por recuperar a discussão sobre ação e agentes econômicos, economicamente condicionados e economicamente relevantes, no sentido weberiano, e que vem inspirando parte importante da configuração teórica da Nova Sociologia Econômica. Em seguida, procura apresentar o atual perfil corporativo da companhia, principal agente econômico em análise, para o qual a expansão da atividade mineradora, especialmente em Congonhas, representa um elemento essencial de sua estratégia corporativa. A importância relativa dos segmentos de mineração e siderurgia nessa estratégia constitui-se, desde já decisiva, mas deve condicionar, de forma ainda mais profunda, sua operação nos próximos anos. Adiante, o artigo apresenta uma caracterização das especificidades da ação contestatória em Congonhas, procurando dimensionar estratégias, táticas e expectativas dos agentes envolvidos, seus perfis e alguns resultados dessa disputa, ainda em curso. Sobretudo, busca operacionalizar a ação economicamente relevante a partir de uma arena de conflito erigida em torno da mineração de ferro.

\section{As formas econômica e economicamente relevante da ação}

0 "fato básico" da satisfação de necessidades humanas - materiais e ideais - em face de meios externos escassos e indispensáveis mediante a transformação da natureza constitui, para Max Weber, a fundação da problemática sociológica, ou melhor, institui "um problema de ciência social" (2003, p. 19). Essa "disciplina que a si própria propôs, como alvo, estudar o alcance do fato básico citado" (Ibid., p. 20), através dos acontecimentos da vida cultural direta ou indiretamente ligados a ele deve, portanto, estender seus interesses teórico-empíricos para além dos fenômenos tradicionalmente definidos por econômicos.

A discussão teórica aqui proposta busca resgatar a tipologia dos "problemas econômico-sociais” (Ibid.) como uma contribuição à operacionalização da proposta de ampliar o escopo da análise sociológica da economia. A intuição weberiana original distingue "os acontecimentos, complexos de normas, as instituições etc., cujo significado cultural 
reside [...] no seu aspecto econômico" dos fenômenos não econômicos, mas que sofrem influência, quanto a alguns de seus aspectos mais importantes, "de motivos econômicos" (Ibid.). De fato, uma oposição aparente entre os chamados fenômenos econômicos e os "economicamente condicionados" (Ibid.) vem sustentando a controvérsia elementar entre abordagens material-deterministas da sociedade e autonomistas da economia que alimentou o próprio revigoramento da Sociologia Econômica.

No entanto, a distinção operada por Weber apontava, ainda, outra "categoria de fenômenos" que, "em determinadas circunstâncias, podem adquirir uma importância econômica sob esse ponto de vista, dado que deles resultam determinados efeitos que nos interessam sob uma perspectiva econômica" (Ibid.). Assim, o complexo de fenômenos definidos como economicamente relevantes aponta, fundamentalmente, para o problema da agência, isto é, da ação social, entendida "quanto a seu sentido visado pelo agente" e, referida, portanto, ao comportamento de $o u$ tros" (WEBER, 2000, p. 3). Ademais, a ação e o agente fundam, ainda, formas organizacionais e institucionais cuja importância específica diz respeito, potencialmente, à sua capacidade de influência sobre ações, agentes, organizações, instituições e demais fenômenos econômicos stricto sensu.

Conflitos emergem, assim, a partir de formas de ação e tipos de agentes, em grande medida, econômicos, potencialmente capazes de introduzir regimes de apropriação, uso e significação impositivos em âmbito territorial. A centralidade da ação e do agente econômicos na emergência dos conflitos socioambientais é, portanto, derivada da capacidade transformadora ou desenvolvimentista de grandes projetos de investimento (GPIs), definidos como inversões volumosas e concentradas em redes de atividades industriais extrativas e de transformação e, portanto, caracterizadas por amplo impacto potencial, ambiental e socioeconômico (VAINER, 1989).

Entretanto, a disputa material é insuficiente para explicar a emergência e articulação de formas de ação e agentes economicamente relevantes, em particular, sociais ${ }^{3}$. Em grande medida, conflitos socioambientais envolvem uma dimensão relativa à disputa por bens comuns e, no caso em tela, em Congonhas, a disputa enfoca tais bens a partir de uma doxa cultural, vinculada a uma compreensão da dimensão simbólica do espaço e do território. Neste caso, em especial, noções contraditórias acerca do patrimônio cultural e histórico do município condicionam a adesão da opinião pública à campanha conflitiva-chave, acerca da Serra Casa de Pedra.

A ação e o agente economicamente relevantes são, então, motivados duplamente, em âmbitos material e simbólico, sendo potencialmente capazes de instituir arenas (DE SARDAN, 2005) de ações e agentes diversificados. Se, por um lado, essa proposta permite uma análise em termos de agências múltiplas, hierárquicas e interativas; de outro, adota um postulado subjacente, aderindo a um paradigma de relações sociais conflituosas (RAMALHO, SANTOS e LIMA, 2013).

A arena territorial dos conflitos socioambientais é apreendida, assim, como espaço onde "grupos estratégicos heterogêneos se confrontam, levados por interesses mais ou menos compatíveis (materiais ou simbóli- 
cos), com os atores possuindo diferentes níveis de influência ou poder" (DE SARDAN, 2005, p. 186). Ela diz respeito, portanto, à ação economicamente relevante da perspectiva dos meios ou recursos empregados por agentes sociais e políticos locais.

Nesse sentido, se busca operacionalizar uma compreensão empiricamente adequada do problema da ação ao nível das escalas local e (sub)nacional, estruturadas a partir de reações de poder e impelidas por grandes projetos de investimento (GPIs) como arenas conflituosas. 0 enfoque analítico é, portanto, predominantemente construído em torno da ação e do agente social, à medida que economicamente relevantes.

Dessa perspectiva, agentes sociais enraizados territorialmente (HESS, 2004) tendem a ser impelidos a agir reativamente por fenômenos econômicos de grande monta, produzindo assim, arenas de conflito específıcas. Essas formas de ação, concretizadas por meio de greves, manifestações, boicotes, campanhas de opinião etc., instituem, de maneira geral, um gradiente de contestação social (HOMMEL e GODARD, 2005) à ação econômica e a seus operadores (agentes econômicos) e reguladores (agentes políticos).

Assim, o conceito de contestação social remete, em sua forma original, à oposição dos agentes sociais a estratégias corporativas, efetiva e/ou potencialmente arriscadas, particularmente nos âmbitos da saúde pública e do meio ambiente (HOMMEL e GODARD, 2005). Riscos associados a atividades econômicas tornam-se, assim, objeto de esforços de construção social, isto é, de sua conformação como problema ou questão pública, a partir da proposição de discursos e contra-discursos descritivos e ex- plicativos, do estabelecimento de vínculos entre opções tecno-científicas e estratégias corporativas, da imputação de encargos empresariais e político-institucionais etc., configurando disputas em torno da legitimidade da ação econômica.

Considerando a intensidade da exploração de bens naturais promovida pela mineração de ferro, e particularmente, os volumes de matéria-prima, energia e água envolvidos em seus processos extrativos e de processamento primário, esse subsetor se encontra particularmente sujeito à contestação social. Nesse sentido, níveis de ruído e de emissão de efluentes e particulados atmosféricos, de uso de água bruta e reutilização, de controle e disposição de resíduos etc. se encontram permanentemente em disputa, reconstruindo as fronteiras entre legalidade e legitimidade ${ }^{4}$.

0 modelo evolucionário da contestação social proposto por Hommel e Godard (Ibid.) é, ainda, plenamente compatível com a noção de arena previamente defendida. Considerando que a contestação social deve ser apreendida como processo, isto é, como conjunto complexo de ações em torno de um GPI, cuja evolução depende da interação dos principais agentes envolvidos, a unidade de análise se desloca das ações e agentes diversificados individuais para os processos interativos que se estabelecem no território, isto é, na arena.

A despeito do caráter 'gerencial' da formulação proposta - de modo que a estratégia corporativa em setores contestáveis é entendida, em parte, como gestão antecipatória da contestabilidade - a abordagem analítica em termos de padrões de ação e reação dos agentes, econômicos, políticos e sociais, permite considerar resultados mais

4. A legalidade da ação econômica é, essencialmente, fundada em formas de legitimidade prévias e implícitas, sendo o conhecimento tecnocientífico uma de suas dimensões-chave. 
amplos do que os originalmente propostos. Conjugada a um paradigma de relações sociais conflituosas em torno da materialidade e simbolismo dos bens naturais e comuns em disputa - diretamente referidos às condições e formas de reprodução social de indivíduos, grupos e classes sociais - a contestação social abrange, inclusive, a possibilidade de confronto político (TARROW, 2009).

Nesse sentido, é possível estabelecer uma relação de continuidade analítica entre as noções de contestação social e de confronto político. 0 pressuposto assumido é o de que a contestação social constitui um processo evolutivo fundado na interação entre agentes estabelecidos e desafiantes, de modo que suas ações e reações moldam um contexto conflituoso, que pode produzir, ou não, confronto político - concebido como forma contestatória agravada ou mesmo autônoma.

Dessa forma, o exercício da contestação social envolve conjuntos variados de agentes, em especial, sociais, que desempenham ações, rotinas e performances políticas confrontacionais (TILLY e TARROW, 2007). Essas noções adquirem conteúdos empíricos institucionalizados através de eventos, greves, piquetes, boicotes, comícios etc.; mas também desafiam a ordem jurídico-legal, em níveis que vão da ocupação e (re) tomada de espaços e bens disputados, mesmo que demonstrativa e temporariamente, e podem assumir formas de confrontação violenta, através de manifestações, protestos, invasões, destruição de bens privados, saques, dentre outros. 0 confronto político, em sua forma violenta, consistiria no nível mais elevado da contestação social, estando contido, no entanto, em suas formas iniciais, enquanto potência.

Importa, no entanto, considerar a capacidade destas formas de ação de assumir relevância econômica, isto é, de influenciar, de forma integrada, e a partir dos conflitos reais entre os agentes em interação em uma arena territorial, a ação econômica e seus agentes, tanto de forma direta quanto indireta.

\section{Estratégia corporativa e mineração de ferro em Congonhas}

Congonhas é um município localizado no chamado Quadrilátero Ferrífero ${ }^{5}$, região marcada pela abundância de minérios bandeados (banded iron formations, BIF's) do tipo lake superior, característica que a tornou a maior jazida de minério de ferro brasileira até a descoberta da Província Mineral de Carajás (PA), em fins dos anos 1970. Nesse sentido, o Quadrilátero Ferrífero vem sendo, desde a descoberta de suas reservas, a principal região concentradora dos investimentos da indústria extrativa mineral no Brasil, em particular aqueles relacionados à exploração de ferro.

Congonhas, por sua vez, reúne algumas das principais infraestruturas de explotação ou lavra de minério de ferro do Quadrilátero Ferrífero, sediando duas das maiores minas de ferro operacionais no Brasil. Da mina Casa de Pedra, de propriedade da Companhia Siderúrgica Nacional S.A. (CSN), foram extraídas 55 milhões de toneladas (Mt) de minério de ferro em 2013, superando largamente o total extraído da

5. 0 Quadrilátero Ferrífero é definido como "uma estrutura geológica cuja forma se assemelha a um quadrado, perfaz uma área de aproximadamente $7000 \mathrm{~km} 2$ e estende-se entre [...] Ouro Preto a sudeste, e Belo Horizonte, [...] a noroeste", que reúne cerca de 150 minerais já identificados (ROESER e ROESER, 2013, p. 33-34). 
mina Viga (3,5 Mt) - sob controle da Ferrous Resources do Brasil Ltda. (MINÉRIOS e MINERALES, 2014, p. 32; 34). 0 município abriga, ainda, operações extrativas relevantes nas minas Engenho (2,3 Mt) e Fernandinho (1,4 Mt), ambas da Nacional Minérios S.A. (Namisa) ${ }^{6}$ (Idem, 2012, p. 25).

Quadro 1 - Principais minas de ferro por produção anual em toneladas (ROM*), Congonhas $(2011 ; 2013)$

$\begin{array}{lllllll}\text { Pos. } & \text { Nome } & \text { Empresa } & \text { ROM (T)/2013 } & \begin{array}{l}\text { Produção (ROM) } \\ \text { estimada 2014 }\end{array} & \begin{array}{l}\text { Produção (ROM) } \\ \text { estimada 2015 }\end{array} & \begin{array}{l}\text { Classe de } \\ \text { Mina** }^{* *}\end{array} \\ 3 & \text { Casa de Pedra } & \text { CSN } & 55.000 .000 & - & - & \text { G2 } \\ 49 & \text { Viga } & \begin{array}{l}\text { Ferrous } \\ \text { Resources }\end{array} & 3.500 .00 & 8.000 .000 & - & \text { G2 } \\ & & & & & & \\ \text { Pos. } & \text { Nome da Mina } & \text { Empresa } & \text { ROM (T)/2011 *** } & \begin{array}{l}\text { Produção (ROM) } \\ \text { estimada 2012 }\end{array} & \begin{array}{l}\text { Produção (ROM) } \\ \text { estimada 2013 }\end{array} & \begin{array}{l}\text { Classe de } \\ \text { Mina }\end{array} \\ 62 & \text { Engenho } & \text { Namisa } & 2.347 .100 & 2.308 .085 & 3.877 .034 & \text { G1 } \\ 82 & \text { Fernandinho } & \text { Namisa } & 1.431 .575 & 1.488 .546 & 1.491 .919 & \text { G1 }\end{array}$

Fonte: (MINÉRIOS e MINERALES, 2012; 2014).

* Run of mine (ROM), minério bruto ou diretamente extraído, sem processamento.

** O Departamento Nacional de Produção Mineral (DNPM) classifica as minas em três categorias de porte, grande, média e pequena, sendo as primeiras subdivididas em duas classes G1 (acima de 3 milhões de toneladas por ano, Mtpa) e G2 (acima de 1 Mtpa). *** A repetição da linha de título da tabela separa duas referências temporais $(2011 ; 2013)$. Em razão de investimentos recentes no setor, as minas de Engenho e Fernandinho saíram do rol das "200 Maiores Minas Brasileiras", não sendo possível obter dados comparáveis para 2013.

Dadas as limitações de espaço e o caráter concentrado dos investimentos minerais em operação em Congonhas, de um lado; e o caráter transformador de um único grande projeto de investimento (GPI) projetado pela CSN do outro, a análise nesta seção concentrar-se-á no 'nó' minerador de ferro da rede de produção desta firma em particular.

A CSN é um dos maiores produtores de aço no Brasil ${ }^{7}$. Em 2013, a produção brasileira de aço bruto alcançou 34,2 Mt e, sozinha, a Usina Presidente Vargas (UPV), em Volta Redonda (RJ), produziu 4,5 Mt . A UPV produz ainda, o portfólio mais completo e diversificado de aços planos da América Latina. Até então caracterizada por uma operação essencialmente nacional, a CSN opera hoje através de uma rede de produção internacional, que busca se transnacionalizar. A firma é gerida como uma holding company, possuindo participações e controle acionário de uma grande variedade de outras companhias (cf. Quadro 2) em cinco segmentos de negócio: cimento, energia, logística, mineração e siderurgia. É controlada, por sua vez, pela holding Vicunha Siderurgia S.A., braço siderúrgico do grupo Vicunha S.A., oriundo do setor têxtil.

6. Além destas, são ainda dignas de nota as minas Fazenda Coelhos, operada pela Ferro Mais Mineração Ltda. (Ferro Mais); e Fábrica, sob controle da Vale S.A.

7. 0 parque siderúrgico nacional é composto por 29 usinas (48,4 Mtpa de capacidade produtiva), controladas por 11 diferentes grupos empresariais. 0 referido parque é responsável por 124.059 postos de trabalho (IAB, 2014).

8. A UPV, inaugurada em 1946, possui capacidade produtiva da ordem de 5,6 Mtpa. 
Quadro 2 - Participações Societárias da CSN

\begin{tabular}{|c|c|c|c|}
\hline Empresas & $\%$ & Empresas & $\%$ \\
\hline \multicolumn{2}{|c|}{$\begin{array}{l}\text { Participação direta em controladas: } \\
\text { consolidação integral }\end{array}$} & CSN Holdings (UK) Ltd & 100 \\
\hline CSN Islands VII Corp. & 100 & \multicolumn{2}{|l|}{ CSN Handel GmbH } \\
\hline CSN Islands VIII Corp. & 100 & \multicolumn{2}{|l|}{ Companhia Brasileira de Latas } \\
\hline CSN Islands IX Corp. & 100 & \multicolumn{2}{|l|}{ Rimet Empreendimentos Industriais e Comerciais S. A. } \\
\hline CSN Islands X Corp. & 100 & \multicolumn{2}{|l|}{ Companhia de Embalagens Metálicas MMSA } \\
\hline CSN Islands XI Corp. & 100 & \multicolumn{2}{|l|}{ Companhia de Embalagens Metálicas - MTM do Nordeste } \\
\hline CSN Islands XII Corp. & 100 & \multicolumn{2}{|l|}{ Companhia de Embalagens Metálicas - MTM } \\
\hline CSN Minerals S.L.U. & 100 & CSN Steel Comercializadora S.L.U. & 100 \\
\hline CSN Export Europe S.L.U. & 100 & CSN Steel Holdings 1 S.L.U. & 100 \\
\hline CSN Metals S.L.U. & 100 & CSN Steel Holdings 2 S.L.U. & 100 \\
\hline CSN Americas S.L.U. & 100 & Stalhwerk Thüringen GmbH & 100 \\
\hline CSN Steel S.L.U. & 100 & CSN Steel Sections UK Limited & 100 \\
\hline TdBB S.A & 100 & CSN Steel Sections Polska Sp. Z.o.o & 100 \\
\hline Sepetiba Tecon S.A. & 100 & CSN Asia Limited & 100 \\
\hline Mineração Nacional S.A. & 100 & \multicolumn{2}{|l|}{$\begin{array}{l}\text { Participação direta em controladas em conjunto: } \\
\text { consolidação proporcional }\end{array}$} \\
\hline Companhia Florestal do Brasil & 100 & Itá Energética S.A. & 48,8 \\
\hline Estanho de Rondônia S.A. & 100 & CGPAR - Construção Pesada S.A. & 50 \\
\hline Cia Metalic Nordeste & 100 & Consórcio da Usina Hidrelétrica de Igarapava & 17,9 \\
\hline Companhia Metalúrgica Prada & 100 & \multicolumn{2}{|l|}{$\begin{array}{l}\text { Participação direta em controladas em conjunto: } \\
\text { equivalência patrimonial }\end{array}$} \\
\hline CSN Cimentos S.A. & 100 & Nacional Minérios S.A. & 60 \\
\hline $\begin{array}{l}\text { CSN Gestão de Recursos } \\
\text { Financeiros Ltda. }\end{array}$ & 100 & MRS Logística S.A. & 27,3 \\
\hline Congonhas Minérios S.A. & 100 & Aceros Del Orinoco S.A. & 31,8 \\
\hline CSN Energia S.A. & 100 & CBSI - Companhia Brasileira de Serviços de Infraestrutura & 50 \\
\hline $\begin{array}{l}\text { FTL - Ferrovia Transnordestina } \\
\text { Logística S.A. }\end{array}$ & 88,4 & Transnordestina Logística S.A. & 62,7 \\
\hline \multicolumn{2}{|c|}{$\begin{array}{l}\text { Participação indireta em controladas: } \\
\text { consolidação integral }\end{array}$} & \multicolumn{2}{|l|}{$\begin{array}{l}\text { Participação indireta em controladas em conjunto: } \\
\text { equivalência patrimonial }\end{array}$} \\
\hline $\begin{array}{l}\text { Companhia Siderúrgica } \\
\text { Nacional LLC }\end{array}$ & 100 & Namisa International Minérios SLU & 60 \\
\hline CSN Europe Lda. & 100 & Namisa Europe, Unipessoal Lda. & 60 \\
\hline CSN Ibéria Lda. & 100 & Namisa Handel GmbH & 60 \\
\hline CSN Portugal, Unipessoal Lda. & 100 & MRS Logística S.A. & 6 \\
\hline $\begin{array}{l}\text { Lusosider Projectos } \\
\text { Siderúrgicos S.A. }\end{array}$ & 100 & Aceros Del Orinoco S.A. & \\
\hline Lusosider Aços Planos S. A. & 100 & Namisa Asia Limited & 60 \\
\hline CSN Acquisitions Ltd. & 100 & \multicolumn{2}{|l|}{ Participação direta em coligadas: equivalência patrimonial } \\
\hline CSN Resources S.A. & 100 & Arvedi Metalfer do Brasil S.A. & 20 \\
\hline
\end{tabular}

Fonte: (CSN, 2014) 
Desde o início de suas operações, a empresa adotou uma estratégia de integração vertical à montante, anexando, por exemplo, as minas Casa de Pedra (minério de ferro) e da Bocaina (calcário e dolomita) - respectivamente em Congonhas e Arcos (MG), tornando-se autossuficiente quanto a estes insumos. No entanto, a passagem das décadas de 1980 e 1990 foi central para a companhia quanto à alteração do paradigma produtivo (reestruturação com vistas à acumulação flexível, a partir de 1989) e da estrutura de propriedade, com a privatização, em 1993. Desde então, a empresa intensificou sua estratégia de integração vertical, adquirindo o controle sobre a Vale S.A. (1997), posteriormente revertido (2001), e ingressou no setor de infraestrutura através do controle sobre companhias ferroviárias, energéticas e operadores portuários, dentre outros.

A despeito da complexidade de suas operações, a literatura especializada deu pouca (RADY, 1973) ou nenhuma ênfase (MOREL, 1989; PIQUET, 1998; GRACIOLLI, 2007) à investigação integrada dessas operações, que representou o elemento determinante do projeto de implantação da 'grande siderurgia' no Brasil. Faz-se necessário, portanto, abordá-las da perspectiva da rede de produção mínero-siderúrgica, de modo a apreender a importância diferencial dos territórios (nodos extrativos, produtivos e logísticos) na estratégia corporativa da CSN. Somente no Brasil, a empresa atua diretamente em nove estados, através de subsidiárias como a Prada, a Inor, a ERSA e a METALIC.
Segundo Germano de Paula (2011), a internacionalização patrimonial da CSN se deu basicamente em três fases. A primeira delas, através da aquisição da norte-americana Heartland Steel como estratégia de superação do protecionismo contra o aço importado imposto pelas autoridades locais; e de 50\% das ações da portuguesa Lusosider, pertencentes à então Arcelor, forçada a vendê-las por uma imposição da Comissão Europeia. A segunda fase se deu entre os anos de 2009 e 2011 com a compra da mina de Riversdale, na Austrália, e sua posterior revenda (por cerca de US\$ 830 milhões) para a Rio Tinto. E, por fim, a CSN passou por uma terceira fase, iniciada em 2011, com a compra de um conjunto de ativos então pertencentes ao Grupo Alfonso Gallardo (GAF), com sede na Espanha. Entre os ativos, incluíam-se duas mini mills ${ }^{9}$ (a Stahlwerk Thüringen, na Alemanha, e a Corrugados Azpeitia, na Espanha) e uma cimenteira (Cementos Balboa, na Espanha) (Ibid.).

A identificação de uma parte representativa da rede de produção da CSN (cf. diagrama abaixo) pode, assim, produzir um melhor entendimento das estruturas econômicas, políticas e sociais que definem sua operação em territórios específicos. Nesse sentido, considerando as lacunas de conhecimento acerca das operações de extração, beneficiamento primário e transporte mineral da CSN, assim como a impacto dos processos territoriais em curso, esta seção enfoca fundamentalmente as operações localizadas no município de Congonhas.

9. Mini mills são usinas siderúrgicas semi-integradas, se caracterizando pelo refıno através de forno elétrico a arco (Electric Arc Furnace, EAF) e uso de sucata de ferro e aço como matéria-prima básica (SANTOS, 2010). 


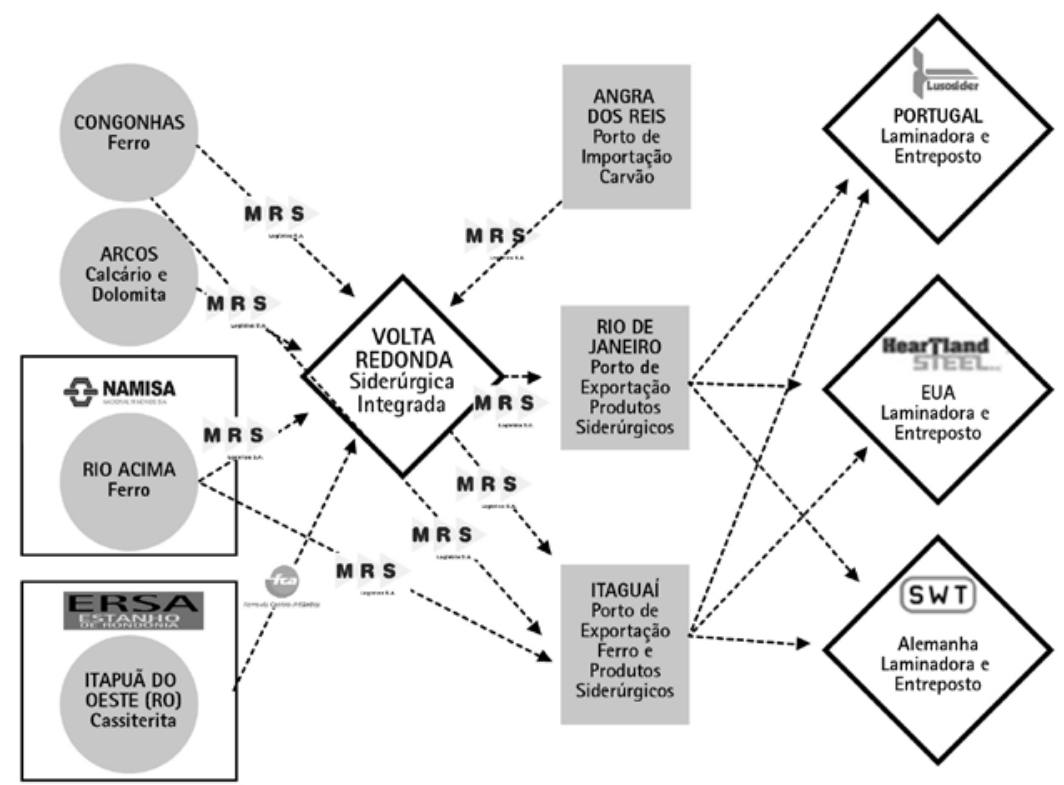

Fonte: produzido pelo autor

Nesse sentido, o deslocamento do investimento da CSN para o nodo extrativo converteu a mina Casa de Pedra, operacional desde 1913, e nacionalizada em 1943, assim como o município de Congonhas, em elementos centrais para a manutenção da posição do grupo na rede global de produção (RGP) mínero-siderúrgica (HENDERSON et al., 2011; WILSON, 2013). A mina, de 3,488ha (MINÉRIOS e MINERALES, 2013), atingiu em 2013 a capacidade de extração de $55 \mathrm{Mtpa}^{10}$ a partir de suas três cavas (corpos Principal, Norte e Oeste) atualmente em operação.

A projeção inicial da CSN estimava que a criação de nova capacidade produtiva na mina totalizasse 70 Mtpa, além da instalação de uma nova pelotizadora, com capacidade de processamento de 3,3 Mtpa. Entretanto, sua expansão planejada de capacidade instalada para 89 Mtpa até 2015 e, posteriormente, até 100 Mtpa (ALERIGI JR., 2012), deu origem e vem sustentando importantes reações de contestação social em escala local. 0 cerne da argumentação contestatória diz respeito à alteração paisagística e ao impacto sobre os recursos hídricos potencialmente provocados pelo projeto.

A orientação com vistas à composição integral ${ }^{11}$ de redes de produção, no interior das quais atividades logísticas tornam-se

10. Casa de Pedra supre integralmente as necessidades deste minério por parte da UPV, e ainda comercializa seu excedente nos mercados interno e externo. Sua força de trabalho era de 2.427 empregados diretos, divididos entre a lavra (1.044), o beneficiamento (641), cargos administrativos (499) e outros (244) em 2012. Os terceirizados correspondiam a 3.998 trabalhadores (MINÉRIOS e MINERALES, 2013).

11. No que concerne às matérias-primas do processo siderúrgico, a CSN satisfaz cerca de $1 / 4$ de sua demanda de carvão mineral e coque fora de sua rede (cerca de 3,3 Mtpa. provenientes das Austrália, Canadá, EUA, Indonésia etc.), assim como a totalidade de sua demanda por zinco e alumínio no mercado doméstico. 
centrais à estratégia corporativa, representa assim, o rationale específico dos segmentos mínero-siderúrgicos em face do processo inovativo contínuo, que desgasta progressivamente sua lucratividade no longo prazo; e da difusão tecnológica, operada pela cisão estrita entre transnacionais produtoras de aços especiais e produtores nacionais de aço bruto.

Apenas considerando esta reorientação estratégica da holding CSN é que podem ser entendidos tanto os esforços pelo controle integral da operação da mina Casa de Pedra - no esteio do descruzamento acionário com a Vale S.A. - e pela ampliação inaudita de sua capacidade de produção, quanto a constituição da Namisa em 2006 (CADE, 2009). Admite-se, assim, como uma das premissas-chave desta interpretação da estratégia corporativa da CSN, que o processo de integração em rede do grupo pode representar, predominantemente, a mudança de seu core business, justificada conjunturalmente, da siderurgia à mineração de ferro ${ }^{12}$.

[...] a intenção da CSN sempre foi, e hoje continua sendo, a longo prazo, ganhar dinheiro fazendo aço, mas a oportunidade, com esse boom de crescimento da China, a partir de 2001, 2002, que acelerou mais o crescimento chinês, aumentou a demanda por minério de ferro. Começou a faltar minério de ferro e sobrar aço. Hoje em dia sobra aço no mundo e falta minério de ferro. 0 minério de ferro está sobrevalorizado e com a percepção disso, já desde 2005, 2006, a CSN começou a: "Não, então vamos nos desenvolver em mi- nério de ferro, vamos ganhar muito dinheiro com minério de ferro, e depois a gente investe em aço". Você ganha US\$ 100 por tonelada vendendo minério de ferro e ganha US\$ 250 por tonelada vendendo aço, em condições normais. Então, é muito melhor você fazer aço do que fazer minério de ferro. Só que pra você investir, pra tirar uma tonelada de minério, você investe US\$ 100 por tonelada, e pra fazer uma tonelada de aço você investe US\$ 1000 por tonelada. Então, o aço é muito mais capital-intensivo. Ele exige equipamentos de grande porte. 0 aço demanda mais capital pra gerar mais riqueza; gera mais riqueza, mas demanda mais capital. [...] E a mineração já não é. Você, com relativamente baixos investimentos, já consegue gerar bastante retorno. Então em função disso - isso já está ocorrendo desde 2007 - a CSN investiu muito, hoje já está com a capacidade instalada da ordem de 40 milhões de toneladas por ano. 0 consumo nosso aqui é da ordem de 8 milhões de toneladas por ano, aqui na usina, e o restante é para venda, é para exportação, basicamente para China. Nós temos o porto, foi desenvolvido... A ideia é exportar acima de 30 milhões de toneladas por ano. Acho que a gente vai conseguir (REPRESENTANTE DA CSN, 2012).

A Namisa constituiria um primeiro passo da referida reorientação ${ }^{13}$, tendo sido criada com vistas à compra de minério de ferro de produtoras junior para exportação (CADE, 2009). Assim, fora avaliada em US\$ 7,8 bilhões já em 2008 (PLANNER, 2008) e a CSN negociou a venda de $40 \%$ de parti-

12. 0 jornal Valor Econômico expressa com clareza esta reorientação: "A Namisa faz parte da estratégia de Steinbruch de tornar a CSN uma produtora de 90 milhões de toneladas de minério por ano dentro de quatro a cinco anos" (2009).

13. Em julho de 2007, essa diretriz foi potencializada com a aquisição do controle integral da Companhia de Fomento Mineral e Participações S.A. (CFM), por US\$ 440 milhões. 
cipação no capital de sua subsidiária com a holding de propósito específico Big Jump Energy Participações S.A. (Big Jump) por US\$ 3,12 bilhões ${ }^{14}$.

A Big Jump fora composta pelo consórcio japonês Brazil Japan Iron Ore Co. (BJIOC) ${ }^{15}$, com 83,8\%, e pela siderúrgica sul-coreana Pohang Iron and Steel Co. (Posco), com 16,2\% (INOUE e KIM, 2008; CADE, 2009; JB e RIBEIRO, 2011). 0 rationale específico da operação é claramente export-oriented, considerando a composição do consórcio liderado pela Itochu, o compromisso de vendas de minério ${ }^{16}$ e prestação de serviços logísticos no Porto de Itaguaí (RJ) aos parceiros envolvidos ${ }^{17}$, assim como a transferência de participação na MRS Logística S.A., MRS (VALOR ECONÔMICO, 2009).

0 consórcio se justificava em face da necessidade de garantir acessos privilegiados a matérias-primas cruciais (WILSON, 2013), como o minério de ferro e o carvão, na competição com siderúrgicas verticalmente integradas. Nesse sentido, o assédio das holdings ArcelorMittal e Tata Steel e o interesse da Baoshan Iron \& Steel Co., Ltd. (Baosteel) e de um consórcio liderado pela Jiangsu Shagang Group Co., Ltd. (Shaosteel) (INOUE e KIM, 2008), demonstram a importância estratégica de seus ativos.

Desse modo, a Namisa passou a atuar na extração e processamento primário de minério de ferro, detendo ainda direitos minerários não explorados (CADE, 2009). Em 2009, operava duas minas: Engenho - em Congonhas (MG) ${ }^{18}$, e Fernandinho - em Rio Acima (MG) ${ }^{19}$, assim como duas usinas de beneficiamento em ambas as localidades.

Estima-se que a empresa ${ }^{20}$ constitua brevemente a principal plataforma de exportação de minério de ferro da CSN. Até 2013, os planos de investimento contemplavam a ampliação da capacidade de extração para 13 Mtpa próprias e a comercialização de outras 20 Mtpa oriundas da mina Casa de Pedra e mais 6 Mtpa de produtoras junior locais - totalizando $39 \mathrm{Mtpa}^{21}$; e previam ainda duas usinas de pellet feed, com 6,5 Mtpa de capacidade de beneficiamento, além de escritórios de comercialização na Ilha da Madeira, Portugal e em Hong Kong, China (VALOR ECONÔMICO, 2009).

14. Além de 10\% de participação no capital social da MRS Logística S.A. (PLANNER, 2008).

15. Representando a $4^{\text {a }}$ maior trading japonesa, a Itochu Co. (Itochu), com 40\%; e as siderúrgicas JFE Holdings Inc. (JFE), 16,2\%; Nippon Steel Co. (NSC), 16,2\%; Sumitomo Metal Industries, Ltd. (SMI), 6,6\%; Kobe Steel, Ltd. (Kobe) e; Nisshin Steel Co., Ltd. (NIS).

16. A aquisição dá direito à garantia de fornecimento de 13,7 Mtpa após 2013, o que equivale a 10\% das importações japonesas (INOUE e KIM, 2008).

17. A BJIOC adiantou US\$ 3 bilhões para o pagamento dos serviços logísticos e para a aquisição de minério, em contrato firmado com limite de 35 anos de vigência (VALOR ECONÔMICO, 2009).

18. A mina é parte do Complexo do Engenho, composto também pelas minas: Nogueira Duarte e Argentina, Pires (Pedras Pretas e Água Santa), Pires (Finos de Barragens) e Sobramil.

19. 0 Complexo Fernandinho é composto pelas minas Fernandinho I (Finos de Barragens), Fernandinho II e Cayman; e o de Sarzedo compreende as minas de Carrapato e Mangaba (Finos de Barragens).

20. Em 2011, a NSC e a SMI se retiraram, em função de participações cruzadas na indústria siderúrgica e na mineração de ferro, particularmente no capital social da holding Usinas Siderúrgicas de Minas Gerais S.A. (USIMINAS). Suas participações foram absorvidas pela Itochu e pela JFE (JB e RIBEIR0, 2011).

21. A oposição dos sócios da Namisa - particularmente da NSC, vinha atrasando os planos de expansão da CSN (JB e RIBEIRO, 2011). 
Os limites deste trabalho permitem apenas esquematizar as linhas gerais da rede de produção da CSN. No entanto, é necessário, ainda, apresentar sua dimensão logística, que tem na MRS Logística S.A. (MRS) um eixo crucial. A MRS opera uma extensão de $1.674 \mathrm{Km}$ de linhas férreas - ligando os estados de Minas Gerais, Rio de Janeiro e São Paulo - e transportando, essencialmente, minério de ferro, cimento, produtos siderúrgicos, carvão, ferro gusa, calcário e areia (SANTOS, 2006). Dentre seus principais clientes, a Vale S.A., Vale (11\%) e sua subsidiária Minerações Brasileiras Reunidas S.A. MBR (33\%), de um lado; e a CSN (27\%) e a Namisa (10\%) de outro, aparecem de forma significativa na estrutura acionária da empresa (MRS, 2015).

0 principal corredor ferroviário de exportação de minério de ferro da CSN liga, por sua vez, suas minas no interior do estado de Minas Gerais a uma 'plataforma logística' que tem em Itaguaí seu nodo central. A CSN pretendia investir nesta estrutura cerca de US\$ 2,23 bilhões em expansão entre 2008 e $2013^{22}$, ampliando a capacidade de movimentação de contêineres, carga geral e produtos siderúrgicos mas, principalmente, de minério de ferro para $160 \mathrm{Mtpa}$, e de carvão para 20 Mtpa.

\section{A ação economicamente relevante como contestação social}

Em Congonhas, onde operam a CSN, a Namisa, a Ferrous Resources do Brasil Ltda. (Ferrous Resources), a Ferro Mais Mineração Ltda. (Ferro Mais) e a Vale S.A. (Vale), o gradiente de contestação centra-se na disputa em torno da Serra Casa de Pedra. A princi- pal mina da CSN foi nacionalizada e incorporada pela empresa em 1944 e vem sendo objeto da estratégia de crescimento orgânico da empresa desde 2008, sendo esperada a ampliação de sua capacidade instalada até 89 Mtpa em 2015.

No entanto, a ampliação da lavra mineral implica uma disputa em torno dos bens naturais reunidos na Serra em, ao menos, duas dimensões: material e simbólica. De um lado, ela compreende 29 pontos de captação de água, respondendo por 59\% do abastecimento público municipal (BACIAS DE MINAS, 2011). De outro, abarca o Conjunto Escultórico do Adro da Basílica de Bom Jesus do Matosinhos, reconhecido pela UNESCO como Patrimônio Cultural da Humanidade desde 1985 (Ibid.). Esses dois aspectos vêm configurando o gradiente da contestação a partir de uma arena específica.

A Serra foi objeto de tombamento sob a Lei Orgânica Municipal e a Lei Municipal no 2.697/2007. No entanto, a evolução da contestação assumiu a forma de uma disputa em âmbito legislativo, em torno do Projeto de Lei no 027, de iniciativa popular, sobre a delimitação do polígono de tombamento. Essa disputa foi temporariamente resolvida com sua aprovação, incorporando emenda de liberação de 15\% de seu perímetro para estudos geológicos (Morro do Engenho e Morro do Pilar) e sua sanção pelo Poder Executivo municipal em 2012.

Os processos envolvidos na disputa mais ampla - em torno da Serra como elemento paradigmático do desenvolvimento econômico neste território - remetem tanto a estruturas quanto a formas de agência: econômicas, políticas e sociais. Relacionando essas duas dimensões, a arena assim cria- 
da possui caráter multiescalar, vinculando agentes operacionais diversos. Em particular, no que concerne aos agentes políticos, as motivações inerentes à Prefeitura Municipal de Congonhas (elevação da arrecadação municipal), ao Governo do Estado de Minas Gerais (redistribuição territorial dos royalties) e ao Governo Federal (vias produtiva e redistributiva do crescimento) (MILANEZ e SANTOS, 2013), conformam uma coalizão pró-mineral, afım aos interesses corporativos prevalentes.

No entanto, há agentes sociais implicados na contestação social que reafirmam a centralidade da ação economicamente relevante - sociopolítica, conforme Ramalho (2005) na efetivação das estratégias estatais e corporativas. Mais especificamente, sua vinculação assume duas formas, direta e indireta, em função da relação que estes agentes estabelecem com o conflito socioambiental da Serra Casa de Pedra. Afetados ou interessados diretamente, tais como a comunidade do Pires e o Grupo Rede Congonhas, exercem então, formas de poder coletivo (HENDERSON et al., 2011) e demonstram capacidade de 'atrair' agentes para o conflito, dentre os quais a $1^{\text {a }}$ Promotoria da Comarca de Congonhas se converteu na principal organização a ele indiretamente relacionada.

Os agentes sociais diretos de contestação tematizam concepções institucionais e não institucionais de agência, assim como operam a partir da incorporação e domínio de formas diversas de conhecimento, leigo e perito. Nesse sentido, o Grupo Rede Congonhas, constituído como rede informal de militantes ambientais, depende essencialmente do conhecimento jurídico e dos processos técnicos da mineração de ferro possuídos por seus integrantes. Diferentemente, a mobilização da comunidade do Pires, vem se manifestando como confronto político, como nos exemplos do fechamento da ferrovia operada pela MRS e pelos episódios de ocupação da rodovia BR-040.

Mais importante, no conflito envolvendo o assoreamento de uma nascente de água por parte da Namisa, a dimensão simbólica imanente à relação tradicional da comunidade com o território e com a água vem produzindo outras ações de confronto, como a invasão da 1a Promotoria e da Prefeitura Municipal de Congonhas, em 2009; e a ocupação e limpeza da própria nascente. A vinculação dessas ações com formas organizativas institucionais, como os grupos de reflexão por ruas, organizados pela Igreja Católica, e com a posterior presidência da associação de moradores do bairro; assim como as ligações com o Grupo Rede Congonhas, expressam algum 'sucesso' em mobilizar um princípio moral (do uso consuetudinário da água) como eixo da ação contestatória.

Agentes sociais de contestação indiretos, como a 1a Promotoria, operam dentro de marcos institucionais. No entanto, tematizam também princípios morais envolvidos nos acidentes fatais na mineração, por exemplo, assim como formas coordenadas de ação, com vistas a contrabalançar o poder da coalizão pró-mineral. Dessa forma, a miriade de agentes sociais enfocados expressa capacidades diferenciais de influência sobre estratégias empresariais e estatais (relevância econômica, em sentido weberiano), particularmente no que diz respeito ao fenômeno do desenvolvimento econômico.

Independentemente dos resultados do conflito socioambiental em torno da Serra Casa de Pedra, os dados construídos de forma preliminar apontam para formas específicas de relevância econômica da ação e do agente não econômicos, isto é, para as formas de conhecimento, sua organização em rede e os níveis de desafıo ou institucionalidade da ação e para 
a moralidade imanente às arenas constituídas por conflitos de ordem desenvolvimentista, isto é, conflitos que implicam ameaça à reprodução de grupos e classes sociais.

\subsection{A Comunidade do Pires e o Grupo Re- de Congonhas}

Em particular, o bairro do Pires tem sido diretamente afetado pelas atividades minerárias de ferro. As cinco empresas mineradoras, apresentadas na seção precedente, circunscrevem a comunidade de cerca de quatro mil moradores. 0 caso apresenta uma característica distintiva que o torna representativo do argumento levantado neste trabalho, a saber, de que estratégias corporativas centradas no acesso e uso de bens naturais e/ou comuns vinculam uma estrutura de relações sociais conflituosas (RAMALHO, SANTOS e LIMA, 2013). Isto porque, em geral, bens naturais e comuns já são acessados e utilizados por comunidades tradicionais e/ou indígenas, rurais e/ou urbanas, em escala local e, necessariamente, precisam ser convertidos, política e institucionalmente, em bens ou recursos econômicos. Nesse sentido, o que se contesta socialmente é a própria conversão de bens em recursos.

Eles falam que é propriedade da empresa e que nós estamos nos quintais dela. Não é verdade. Eles é que estão nos nossos quintais. Era assim, livre de acesso, e hoje não é mais. $\mathrm{E}$ as nossas águas, a gente caminhava antes de ser esses mananciais aqui que a COPASA fez, que aqui a gente vê que não tem tratamento algum e que nossa água é limpa, porque é uma nascente (LIDERANÇA COMUNITÁRIA DO PIRES 1, 2012).
No Pires, a controvérsia fundamental diz respeito à disputa pelo acesso e uso da água que, neste caso em especial, é considerada bruta ou não tratada, embora potável. Nesse sentido, na comunidade do Pires, distante cerca de 13,4 km da sede municipal, a relação entre a população e a água se reveste de uma dimensão tradicional e, sobretudo, simbólica. A água bruta representa um traço de continuidade com o passado do bairro e, ao mesmo tempo, projeta concepções acerca do caráter da interação social intracomunitária, isto é, delineia as formas de solidariedade apreciadas. Nesse sentido, as nascentes Boi na Brasa e João Batista, assim como as fontes derivadas de água bruta (rios, regos, fontes, poços, etc.) ocupam um lugar relevante na estrutura social comunitária, e sua preservação antecede concepções ambientais modernas. 0 evento do mutirão comunitário para a limpeza do "regão" explicita alguns desses conteúdos simbólicos ${ }^{23}$ :

Meu pai trabalhava na Ferteco ${ }^{24}$. [...] Ele, quando era o dia que ele se reunia pra fazer esse mutirão, pra fazer essa limpeza desse regão, aí quando eu lembro do meu pai pagando sim, uma outra pessoa pra limpar no lugar dele porque ele tinha que trabalhar. Isso era sagrado. Todo ano. Não era mulher, não. Eram só os homens. [...] Era [questão] de honra. Se meu pai não pudesse ir, ele tinha que pagar uma outra pessoa pra poder ir. Não podia entrar criança nem mulher, eram só os homens. Isso era sagrado. Isso era lei. Todo ano eles se reuniam e tiravam um dia no mês, horário, e eles ficavam o dia todo e só saíam quando terminavam (LIDERANÇA COMUNITÁRIA DO PIRES 1, 2012).

23. A discussão é, ainda, introdutória e se beneficia do debate com a Profa. Dra. Neide Esterci (PPGSA/ UFRJ) e com a mestranda Gabriela Fernandez (UFRJ), às quais o autor registra seu agradecimento. 24. A Ferteco Mineração S.A. foi incorporada pela Vale em 2001 por US\$ 566 milhões. 
Neste exemplo, onde a materialidade e o simbolismo dos bens naturais e comuns convergem, as ameaças potencial e real ao abastecimento de água constituíram o evento matricial que iniciaria a contestação social e, mais importante, o confronto político. 0 evento em questão consistiu no escoamento de material particulado contendo minério de ferro para os córregos e nascentes na comunidade, atingindo seus mananciais. Seu primeiro episódio, em setembro de 2009, foi atribuído ao abandono das obras de engenharia civil para a construção de uma estrada de 8,1 km por parte da Teixeira Prates Engenharia Ltda., subcontratada da Namisa, tendo sido associado à intensidade da chuva, que teria feito o terreno ceder.

A Namisa reconheceu sua responsabilidade no episódio, que se repetiria em outubro de 2010, e participou de audiências públicas da Comissão de Meio Ambiente e Desenvolvimento Sustentável da Assembleia Legislativa (2009) e da $1^{\text {a }}$ Promotoria da Comarca de Congonhas, do Ministério Público Estadual, MPE (2010). A empresa assinou ainda, um Termo de Ajustamento de Conduta (TAC) com o MPE com vistas à mitigação e compensação dos danos infligidos à comunidade. No entanto, da perspectiva da agência economicamente relevante, a contestação social iniciada a partir da organização de base comunitária e com forte componente moral e religioso, foi relevante para a adoção de um padrão de reação interativo por parte da companhia.

0 que a empresa fez? Ela fez uma estrada atrás da Serra e a gente não viu. [...] A gente só soube dessa estrada a hora que a gente estava recebendo barro em casa. Aí começou a água a sair toda suja e ninguém sabia de onde que tava [vindo] essa sujeira. Aí o Pe. Paulinho veio pra cá [...]. E a gente já tava tomando água suja. Aí um dia eu conversando com ele. Ele chegou e falou assim: "Mas não pode ficar desse jeito. Vai ter uma reunião”. [...] Em 2009. [...] Aí eu fui nessa reunião [do Conselho Municipal de Meio Ambiente (CODEMA) de Congonhas]. [...] Aí, a gente de lá já foi pro Ministério Público. Aí eu dei a declaração lá e onde começou tudo. E aí a gente não parou mais de lutar (LIDERANÇA COMUNITÁRIA DO PIRES 2, 2013).

A "luta", sob a forma de contestação social e, sobretudo, confronto político, se materializou, inicialmente, no requerimento de providências institucionais por parte da $1^{\text {a }}$ Promotoria, da Câmara Municipal e também da Prefeitura Municipal de Congonhas. No entanto, a comunidade do Pires, que organizou o transporte de três ônibus com cerca de oitenta moradores, não aceitou a oferta do então Prefeito Anderson Cabido de receber uma comissão de representação e "de repente subiu todo mundo pro gabinete, abriu a porta e foi entrando [...]" (REPRESENTANTE DO REDE CONGONHAS, 2012).

Os questionamentos apresentados pela comunidade foram reforçados pela atuação do Grupo Rede Congonhas - uma rede informal surgida com o propósito de alertar a população do município sobre questões como o tombamento da Serra, o impacto das mineradoras em alguns bairros, como o Plataforma e o próprio Pires etc. Oficialmente datada de 2008, a articulação - composta por um 'núcleo duro' de ex-funcionários de mineradoras começou a se configurar a partir de 2000, quando realizou mutirões para implementar melhorias no trevo de entrada da cidade pela BR-040, trecho marcado pelo alto número de acidentes e atropelamentos. Quando o caso envolvendo a comunidade do Pires tornou-se público, o Rede Congonhas organizou discussões periódicas, 
propôs ações de governo ao (recém-eleito) prefeito Anderson Cabido e se aproximou da $1^{\text {a }}$ Promotoria, procurando viabilizar sua interferência institucional.

0 movimento, podendo assim ser classificado, é dotado de certo conhecimento perito sobre a questão técnico-ambiental da mineração, marcado pelo engajamento e pela politização de seus integrantes, que se encontram divididos entre uma base preservada pela invisibilidade opcional e um corpo flexível de colaboradores mobilizados conforme a necessidade. Com a presença de engenheiros, advogados e técnicos vinculados a uma união de associações de moradores que unifica os bairros e suas demandas, o Grupo Rede Congonhas contribuiu para instrumentalizar a comunidade do Pires em sua mobilização contra a ação das mineradoras.

0 movimento foi criado em 2008, numa época em que a gente não tinha quase que nenhuma experiência na lida com órgãos públicos. A gente nunca tinha mexido com o Ministério Público. [...] Começamos a mexer com esses assuntos, tentando ver uma forma como poderíamos cooperar, acordar a população, tentar atuar institucionalmente de alguma maneira, fazer algo pela cidade, que estava tomando um rumo que a gente viu que não seria muito bom. Mas meio que nos protegendo. Criamos essa ficção que é o Grupo Rede Congonhas, que não tem estatuto, não tem reunião formal, não tem sede etc. Junta- mos inicialmente 4 ou 5 pessoas. Começamos a fazer trocas de ideias e cada um tinha uma aptidão. Cada um levava [...] sua formação, pra gente começar a discutir. [...] Nossa preocupação era muito com a rodovia, por exemplo. [...] E a gente [...] falava muito em trabalhar sob uma cortina de fumaça. Era manter um grupo coeso, contanto que não tivesse visibilidade para quem pudesse nos afetar. [...] 0 embrião do grupo está no ano 2000. A preocupação era com o trevo da cidade (REPRESENTANTE DO REDE CONGONHAS, 2013).

A atuação do Grupo Rede Congonhas complementou, no entanto, formas confrontacionais que parecem constituir um elemento essencial do repertório de ação coletiva da comunidade do Pires, desafiando os agentes políticos e suas práticas institucionalizadas. Assim, em novembro de 2010, cerca de 200 moradores da comunidade ocuparam um ramal ferroviário da MRS, paralisando-o por cerca de três horas, e pleiteando a implantação de uma passarela na passagem de nível localizada no bairro, contra a qual a empresa solicitara a concessão de um interdito proibitório contra a Associação de Moradores do Bairro Pires ${ }^{25}$. A referida tática de ocupação e fechamento de vias de transporte vem sendo, ainda, utilizada de forma recorrente sobre a questão dos atropelamentos na BR040, altura do km 603.

Assim, o atropelamento e falecimento de Natália Maria Firmino, em junho de 2011,

25. 0 Código de Processo Civil (art. 932) define o interdito proibitório como uma ação judicial defensiva e preventiva, voltada à supressão de ameaças de perturbação do exercício da posse. Nesse sentido, tem sido empregado em diferentes contextos por empresas mineradoras e logísticas como mecanismo reativo, antecipando táticas de contestação social apoiadas na ocupação de áreas de explotação e processamento e, sobretudo, sistemas de transporte. Nesse caso, a MRS obteve a concessão de medida liminar de interdito proibitório contra associação de Moradores, determinando a abstenção de novas obstruções da "linha férrea que corta o bairro Pires, sob pena de aplicação de multa" e "crime de desobediência" (TJMG, 2014). 
motivou a interdição da rodovia e a queima de pneus por cerca de oito horas. Do mesmo modo, em junho e julho de 2013, foram registradas novas manifestações em favor da construção de duas passarelas no local, e em agosto, três episódios de protesto em quatro dias, motivados por mais outro atropelamento fatal, impediram o tráfego. "Na terça [06 de agosto], usando pneus, pedaços de madeira e cruzes com os nomes das vítimas de acidentes, [os moradores] [...] montaram uma barricada e interditaram os dois sentidos da estrada por 12 horas" (SILVA, 2013).

Embora a demanda seja destinada à Prefeitura Municipal de Congonhas, em todos os episódios atribui-se responsabilidade ao transporte rodoviário de minério, de modo que mesmo a assessoria de imprensa do Executivo municipal informava a intenção de "cobrar das mineradoras a construção de uma via alternativa [...]. Por dia, [...] passam mais de mil carretas pela BR-040, na altura da Comunidade dos Pires, com mais de 30 toneladas de minério cada" (0 ESTADO DE MINAS, 2011).

De modo consistente ao repertório de ação coletiva comunitário, a contestação social à obstrução do acesso e uso da água no território evoluiria para um confronto político potencial em uma das nascentes contaminadas. Considerando a incidência da mineração sobre a disponibilidade hídrica (SANTOS, 2013) e a centralidade destes recursos para o bairro Pires, a contestação empregou táticas de ameaça de ocupação e sua efetivação. Seu ápice consistiu, assim, na re- tomada - sob responsabilidade institucional da COPASA Águas Minerais de Minas S.A. e limpeza da nascente João Batista. Uma das lideranças comunitárias do Pires expressou o confronto potencial da seguinte forma:

Vamos limpar. Sete horas da manhã, todo mundo na nascente. Fulano vai arrumar um carro e vai buscar comida, o outro grupo vai arrumar refrigerante, porque não tem água... Se vier polícia, não deixa. Se for o caso, pega pau, ali tem muito pau, mete o cacete. Porque não podemos ficar sem água. $\mathrm{E}$ o pessoal foi entrando na nossa [...]. E assim se fez. Aí teve polícia, teve a Polícia Militar, teve a Secretaria do Meio Ambiente, teve Ministério Público, teve todo mundo. Teve COPASA. [...] Então, a gente foi aprendendo como que a Justiça também teme o cidadão. A gente não sabia disso [...]. A comunidade se uniu e se fortaleceu e hoje tudo o que acontece ou o que vai acontecer, eles ligam pra gente (LIDERANÇA COMUNITÁRIA DO PIRES 1, 2012).

\subsection{Ministério Público de MG e a $1^{\text {a }}$ Pro- motoria da Comarca de Congonhas}

0 conjunto de estratégias e táticas de ação social, economicamente relevante, planejadas e executadas por agentes como o Grupo Rede Congonhas e a comunidade do Pires, encontram sua contrapartida institucional legal na ação do Ministério Público de Minas Gerais (MPGM) ${ }^{26}$ e, especificamente, da $1^{\text {a }}$ Promotoria de Justiça da Comarca de Congonhas ${ }^{27}$, a partir de 2008.

26. 0 Ministério Público no Brasil compreende o Ministério Público da União (MPU) - composto pelo Ministério Público do Trabalho (MPT), Ministério Público Militar (MPM), Ministério Público do Distrito Federal e Ministério Público Federal (MPF) - e os Ministérios Públicos estaduais.

27. Dentre as áreas de atuação da $1^{\text {a }}$ Promotoria, destacam-se as de Defesa dos Direitos Humanos; Habitação e Urbanismo; Defesa da Saúde; Defesa do Patrimônio Histórico e Cultural; e Defesa do Meio Ambiente. Há, ainda, uma 2a Promotoria de Justiça na mesma Comarca (MPMG, 2013). 
A emergência do Ministério Público ${ }^{28}$, como instituição integrada ao Poder Judiciário e dotada de relativas independência e autonomia, se dá nos anos 1980. A Política Nacional de Meio Ambiente (Lei n. 6.938, de 31 de agosto de 1981), que reconhece ao MPU e aos MPEs a "legitimidade para propor ação de responsabilidade civil e criminal, por danos causados ao meio ambiente"; a organização dos MPEs (cf. Lei Complementar n. 40, de 14 de dezembro de 1981); e a instituição do mecanismo da Ação Civil Pública, ACP (cf. Lei n. 7.347, de 24 de julho de 1985) são considerados elementos estruturantes "de um outro desenho de suas atribuições: a defesa ativa de interesses difusos e coletivos, ou seja, a proteção, por legitimação extraordinária, de direitos que integram o conceito contemporâneo de cidadania" (BATISTA, 2000, p. 62).

No caso específico da Comarca de Congonhas, a $1^{\text {a }}$ Promotoria foi ocupada em fins de 2008 por Vinícius Alcântara Galvão.

[...] no final de 2008 [...] eu assumo a Promotoria do ponto de vista ambiental. Algumas coisas me chamavam a atenção. Eu recebi alguns relatórios feitos pelas empresas, acerca de poluição atmosférica que é o principal problema detectado pela comunidade. Não o teor de poluição hídrica, mas a poluição atmosférica chama muito a atenção [...]. Nesse período, às vezes têm um arraste eólico muito grande por causa das minas, né, das pilhas de... que eles colocam aí. E eles mandavam pra gente uma... relatórios acerca de auto monitoramentos que eles fizeram.
Aí eu até falei que eu não queria mais aquilo, que eu não considero aquilo, não é oportuno (GALVÃO, 2012).

A primeira ação efetiva de condicionamento do poder corporativo das mineradoras em Congonhas partiu, desse modo, da $1^{\text {a }}$ Promotoria. 0 tema da poluição atmosférica atribuída à mineração de ferro, por seus efeitos visíveis através do acúmulo de poeira, já vinha mobilizando tanto a sociedade civil quanto os principais agentes políticos do município, por exemplo, através da proposta de criação de um sistema de lava-rodas $^{29}$. Entretanto, comportamentos reativos negativos vinham sendo seguidos por parte das principais firmas e, "a CSN, por exemplo, [se] negou peremptoriamente" (GALVÃo, 2012) a participar de sua construção. 0 padrão reativo de negação dizia respeito, portanto, à vinculação entre a atividade mineradora e a poluição atmosférica.

A estratégia implementada pela $1^{\text {a }}$ Promotoria consistiu, então, na produção de informação acerca deste vínculo, a partir do estudo encomendado à empresa de consultoria ambiental ECOSOFT (2012), apresentado em audiência pública ${ }^{30}$. 0 estudo demonstraria, segundo o promotor responsável pela Coordenadoria Regional de Defesa do Meio Ambiente da Bacia dos Rios das Velhas e Paraopeba, Carlos Eduardo Ferreira Pinto, um nexo causal entre a mineração e a poluição do ar em Congonhas.

0 Pires é o bairro mais afetado, ainda que a média anual de emissão de material particulado seja apenas ligeiramente superior ao

28. A origem do Ministério Público no ordenamento institucional brasileiro remonta à 1609, com a criação do Promotor de Justiça e do Procurador dos Feitos da Coroa no Tribunal de Relação da Bahia.

29. A proposta de criação de um sistema de lavagem de rodas dos veículos com acesso às áreas de mineração foi elaborada pela Prefeitura Municipal de Congonhas e contou com o apoio da $1^{\text {a }}$ Promotoria. 30. Realizada na Procuradoria Geral de Justiça de Belo Horizonte em 25 de fevereiro de 2013. 
limite máximo permitido (80 microgramas por m3). Entretanto, é digno de nota que o levantamento tenha sido financiado através de um Termo de Compromisso Preliminar (TCP) entre o MPMG e a Ferrous Resources, em julho de 2010, ainda no processo de licenciamento ambiental da mina Viga ${ }^{31}$.

Segundo o Promotor, "o próximo passo [...] [seria] fazer uma rede integrada de monitoramento da qualidade do ar, identificando as fontes poluidoras e punindo as empresas" (CAMARGOS e FONSECA, 2013). Tal declaração descreve, portanto, uma estratégia de ação em face da controvérsia em torno da qualidade do ar; ação apoiada, fundamentalmente, em conhecimento perito, de forma a reagir eficazmente à pretensão de desresponsabilização e desenraizamento frequentemente levantada pelo agente econômico. No entanto, apresenta ainda outro elemento das estratégias institucionalizadas de ação economicamente relevantes operadas pelo MPMG.

Assim, é ao nível da Coordenadoria Regional, isto é, da ação coordenada em escala estadual, que são formuladas e efetuadas as principais ações de contestação às atividades minerárias e a seus agentes principais em Congonhas. 0 episódio da construção da estrada ligando a mina Engenho à rodovia BR-040, na qual foram poluídas as principais nascentes (Boi na Brasa e João Batista) que abastecem o Pires de água bruta, promoveu, assim, a assinatura de um Termo de Ajustamento de Conduta (TAC) ${ }^{32}$, com a Namisa, em 2011, com vistas à adoção de medidas para sua compensação.
Essa diretriz é exemplificada ainda, pela emissão do Parecer de Recomendação da Preservação do Morro do Engenho, na Serra Casa de Pedra, encaminhado à Câmara Municipal de Congonhas em 2009 (BACIAS DE MINAS, 2011). 0 documento defendia a "necessidade da delimitação do perímetro de tombamento do monumento Serra da Casa de Pedra dentro dos limites propostos no Projeto de Lei de iniciativa popular n 027/2008” (Ibid.). Através dele, o MPMG reconhecia a Serra Casa de Pedra como elemento do "Conjunto Escultórico do Adro da Basílica de Bom Jesus de Matozinhos" (Ibid.), e enfatizava sua relevância para a preservação do equilíbrio ecossistêmico e para o abastecimento hídrico de Congonhas.

Ambas as ações foram efetuadas a partir do intercâmbio constante entre a $1^{\text {a }}$ Promotoria e a Coordenadoria Regional, de modo que potenciais pressões exercidas em escala local tendem a ser minimizadas através da atuação em rede do MPMG. Nesse sentido, as controvérsias acerca da água e do patrimônio histórico de Congonhas vêm sendo travadas em duas escalas de ação integradas, municipal e estadual, da perspectiva desse agente de contestação.

0 inquérito civil que eu mandei lá pra outros colegas em Belo Horizonte é um trabalho em equipe. Eu não vou trabalhar sozinho. É muito complexo. Tem muitos peritos sempre avaliando as situações todas. [...] Quando o inquérito civil tava aqui, que era mais antigo, eu passei até o original pra Belo

31. A firma assumiu ainda, compromissos ambientais compensatórios quanto à Análise de Impactos Cumulativos dos Empreendimentos Mínero-Metalúrgicos e de monitoramento da qualidade do ar.

32. O TAC prevê a execução de projetos de mitigação e de compensação dos impactos ambientais provocados. Quanto à compensação, a empresa deve investir cerca de R\$ 300 mil à recuperação do Centro Comunitário e a um programa de educação ambiental. Além disso, se compromete a realizar a limpeza das caixas d'água e a fornecer água aos moradores durante a implantação da estrada, dentre outras medidas. 
Horizonte e deixei a cópia aqui. Até comuniquei que se tiver que se reunir com a empresa pra alguma coisa, é só lá em Belo Horizonte na Procuradoria, porque eu trabalho em equipe. Então eu só reúno com a minha equipe, quer dizer, eu não posso reunir sozinho. Então, é uma forma bem transparente (GALVÃO, 2012).

\section{Considerações finais}

A presente discussão se propôs a contribuir com o projeto de revigoramento da Sociologia Econômica, ao recuperar a relação entre economia e sociedade, destacando pontos clássicos de tensão entre tais esferas, e evidenciar a aparente oposição entre os fenômenos econômicos e aqueles economicamente condicionados. Além disso, procurou também assinalar a condição de outra categoria de fenômenos, economicamente relevantes, os quais, segundo a perspectiva weberiana, ajudariam a enraizar a agência (sob a forma de ação socialmente orientada) na ordem constitutiva da Economia propriamente e da Sociologia Econômica enquanto campo disciplinar.

No nível empírico, observou-se através da análise que, ao longo do processo de integração almejado pela CSN como parte fundamental da consolidação da sua rede de produção, considera-se fortemente o deslocamento do seu core business da siderurgia para a mineração, fato que vem progressivamente convertendo a Namisa em canal essencial para o aumento da receita operacional com a exportação mineral. A provável ampliação da capacidade produtiva da mina Casa de Pedra tende a confirmar essa condição distintiva alcançada pela Namisa dentro de grupo CSN.

Contudo, o artigo também procurou demonstrar que a ampliação da lavra mine- ral vem implicando em disputas em torno dos recursos naturais constitutivos da Serra Casa de Pedra. Entende-se que o processo de tombamento ajudou a configurar uma arena territorial de disputa, responsável por agrupar os agentes em torno de posições opostas: de um lado, uma coalizão pró-mineral; e, de outro, agentes sociais responsáveis pela contestação da ação econômica. Constituirse-ia, assim, a centralidade da ação economicamente relevante na conformação efetiva das estratégias estatais e corporativas.

Da perspectiva das formas de ação políticas e sociais e dos agentes de contestação, observou-se, em primeiro lugar, uma bifurcação da arena conflituosa relacionada fundamentalmente aos vínculos com o conflito socioambiental da Serra Casa de Pedra, promovendo "novos agentes coletivos", como a comunidade do Pires e o Grupo Rede Congonhas, ao centro da arena; atraindo e influenciando agentes, como a $1^{\text {a }}$ Promotoria da Comarca de Congonhas, a intervir no conflito; e sobrepondo-se, nesse contexto específico, a agentes tradicionais, como o Sindicato Metabase Inconfidentes.

Por sua vez, o artigo evidenciou a mobilização de estratégias e táticas dentro de um gradiente de contestação social, interpretadas a partir da natureza dos desafios que impõem à coalizão pró-mineral, a saber, institucional e não institucional. Em grande medida, as táticas institucionalizadas utilizadas pela $1^{\text {a }}$ Promotoria se apoiaram em concepções de trabalho em rede local-estadual, limitando potenciais pressões corporativas localizadas, e fundadas em conhecimento perito. De forma similar, o Grupo Rede Congonhas também fez uso de sua organização em rede descentralizada e de conhecimentos peritos ambiental, mineral e jurídico, destacando-se pela discrição das ações e exposição limitada de seus membros. 
Entretanto, são as táticas de ação direta, ancoradas em concepções tradicionais sobre o uso dos recursos e do território e, especialmente, em uma relação simbólica com os recursos hídricos, que têm constituído o cerne da contestação social. A comunidade do Pires, principal agente operador das formas não institucionais de ação coletiva, opera o atrelamento da perda de seus direitos sobre bens comuns - como a água - à expansão da mineração como uma injustiça que, como um problema moral, demanda reparação. Dessa forma, recorre a um repertório de ações coletivas rotineiramente mobilizado e sustentado organizacionalmente em práticas religiosas.

Nesse sentido, a análise do conflito socioambiental da Serra Casa de Pedra explicita algumas das principais condições de emergência da contestação social, conjugando pressões materiais e simbólicas à reprodução socioeconômica de um grupo social dotado de integração social, repertório de ação coletiva e recursos organizacionais. De modo mais importante, essas características são reforçadas em uma arena conflituosa, que redefine posições em torno de riscos similares à reprodução do ambiente natural e patrimonial de Congonhas, reunindo agentes sociais e políticos diversificados e dotados de recursos significativos complementares. De fato, as formas de ação economicamente relevante observadas neste conflito vêm expressando complementaridade ao nível dos agentes e de suas estratégias, impactando significativamente o ritmo do projeto de expansão da mina Casa de Pedra e a estratégia corporativa da CSN.

\section{Referências}

ACSELRAD, H. Conflitos ambientais no Brasil. Rio de Janeiro: Relume Dumará, 2004.

ALERIGI JR., A. MG volta a discutir mina da CSN na próxima semana. Reuters Brasil, 2012.

ALTVATER, E. 0 fim do capitalismo com o conhecemos: uma crítica radical do capitalismo. Rio de Janeiro: Civilização Brasileira, 2010. 363p.

BACIAS DE MINAS. MPE recomenda proteção da Serra Casa de Pedra, em Congonhas. Bacias de Minas, 2011.

BATISTA, R. C. Ministério Público e movimentos sociais: uma perspectiva dos direitos difusos e coletivos. Revista do Ministério Público do Distrito Federal e Territórios, n 3, p. 53-72, 2000.

CADE. Ato de Concentração no 08012.011002 /2008-62. 2009.

CAMARGOS, D.; FONSECA, M. D. Congonhas está "sem ar" devido ao pó expelido na exploração de minério. EM, 2013.

CSN. Plataforma Logística CSN em Itaguai: um projeto alinhado às necessidades do Brasil. 2008.

A Companhia: participações societárias. 2014.

DE PAULA, G. M. CSN's internationalisation phase three: commercial flow in the opposite direction. 35: 12 p. 2011.

DE SARDAN, J.-P. 0. Anthropology and Development: Understanding Comtemporary Social Change. London: Zed Books, 2005.

ECOSOFT. Projeto de rede otimizada de monitoramento da qualidade do ar e meteorologia da região de Congonhas. 2012. Disponivel em: <http:// conflitosambientaismg.lcc.ufmg.br/geral/anexos/ PROJET0\%20DE\%20REDE\%200TIMIZADA\%20 DE\%20MONITORAMENT0\%20DA\%20QUALIDADE\%20D0\%20AR\%20E\%20METEOROLOGIA\%20 DA\%20REGI\%C3\%830\%20DE\%20CONGONHAS. pdf>. Acesso em: 20 abr. 2013. 
GALVÃ0, V. A. 2012. Entrevista realizada por SANTOS, R. S. P. et al. 5 ago. 2012.

GRACIOLLI, E. J. Privatização da CSN: da luta de classes à parceria. São Paulo: Expressão Popular, 2007.

HARVEY, D. 0 Novo imperialismo. São Paulo: Loyola, 2005.

HENDERSON, J. et al. Redes de produção globais e a análise do desenvolvimento econômico. Revista Pós Ciências Sociais, v. 9, nº 15, p. 143-140, 2011. HESS, M. Global production networks: dealing with diversity. In: HAAK, R. e TACHIKI, D. S. (Ed.). Regional strategies in a global economy: multinational corporations in East Asia. München: Iudicium, 2004. p.31-52.

HOMMEL, T.; GODARD, 0. Contestação social e estratégias de desenvolvimento industrial: aplicação do modelo da gestão contestável à produção industrial de OGM. In: VARELLA, M. D. e BARROS -PLATIAU, A. F. (Ed.). Organismos geneticamente modificados. Belo Horizonte: Del Rey, 2005. p.251-284.

HORNBORG, A. Zero-Sum World: Challenges in Conceptualizing Environmental Load Displacement and Ecologically Unequal Exchange in the World-System. International Journal of Comparative Sociology, v 50, n 3-4, p. 237-262, June 1, 2009.

IAB. Números de Mercado. MERCADO, D. D. 2014. INOUE, Y.; KIM, M. Asiáticos adquirem 40\% da Namisa por US\$3,12 bi. Reuters Brasil, 2008.

JB; RIBEIRO, I. Cade dá sinal verde para saída da Nippon da Namisa. Valor Econômico, 2011.

LIDERANÇA COMUNITÁRIA DO PIRES 1. 2012. Entrevista realizada por SANTOS, R. S. P. et al. 4 ago. 2012.

LIDERANÇA COMUNITÁRIA DO PIRES 2. 2013. Entrevista realizada por SANTOS, R. S. P. et al. 22 mar. 2013.

MARTINEZ-ALIER, J. Mining conflicts, environmental justice, and valuation. Journal of Hazardous Materials, v. 86, $\mathrm{n}^{\circ}$ 1-3, p. 153-170.
MILANEZ, B.; SANTOS, R. S. P. Neoextrativismo no Brasil? Uma análise da proposta do novo marco legal da mineração. Revista Pós Ciências Sociais, v. $10, \mathrm{n}^{\circ} 19$, p. 119-148, 2013.

MINÉRIOS e MINERALES. Ranking Geral por Produção Anual em Toneladas (ROM) - Ano Base 2011. Minérios e Minerales. São Paulo: p.24-28. 2012.

Perfil das 200 Maiores Minas Brasileiras: Casa de Pedra / Ferro 2013.

Ranking geral por produção anual em toneladas (ROM) - Ano Base 2013. Minérios e Minerales. São Paulo: p. 32-39. 2014.

MOREL, R. L. M. A ferro e fogo - construção e crise da" família siderúrgica": o caso de Volta Redonda (1941-1968). 1989. Tese (Doutorado). Universidade de São Paulo.

MPMG. Promotorias de Justiça da Comarca de Congonhas. 2013. MPMG, 2013.

MRS. Estrutura Acionária. 2015.

O ESTADO DE MINAS. Moradores de Congonhas arriscam a vida em travessia da BR-040. 0 ESTADO DE MINAS, 2011.

PIQUET, R. Cidade-empresa: presença na paisagem urbana brasileira. Rio de Janeiro: Jorge Zahar Editor, 1998. 166 p

PLANNER, C. D. V. S. A. Venda de $40 \%$ da Namisa: +US\$ 3,12 bilhões! Company Alert, 2008.

RADY, D. E. Volta Redonda: a Steel Mill Comes to a Brazilian Coffee Plantation: Industrial Entrepreneurship in a Developing Economy. Albuquerque: Rio Grande Publishing Company, 1973. 380 p.

RAMALHO, J. R. Novas conjunturas industriais e participação local em estratégias de desenvolvimento. Dados, v. 48, p. 491-523, 2005.

; SANTOS, R. S. P.; LIMA, R. J. C. Estratégias de desenvolvimento industrial e dinâmicas territoriais de contestação social e confronto político. Revista Sociologia \&t Antropologia, v. 3 , $n^{\circ}$ 5, p. 175-200, 2013.

REPRESENTANTE DA CSN. 2012. Entrevista realizada por LIMA, R. J. C. 10 ago. 2012. 
REPRESENTANTE DO REDE CONGONHAS. 2012. Entrevista realizada por SANTOS, R. S. P. et al. 1 jul. 2012.

2013. Entrevista realizada por SANTOS, R. S. P. et al. 22 mar. 2013.

ROESER, H. M. P.; ROESER, P. A. O Quadrilátero Ferrífero - MG, Brasil: aspectos sobre sua história, seus recursos minerais e problemas ambientais relacionados. Revista Geonomos, v. 18, $\mathrm{n}^{\circ}$. 1, p. 33-37, 2013.

SANTOS, R. S. P. D. A construção social da região: desenvolvimento regional e mobilização sócio-política no Sul Fluminense. 2006. Dissertação (Mestrado). Programa de Pós-graduação em Sociologia e Antropologia, Universidade Federal do Rio de Janeiro

A Forja de Vulcano: siderurgia e desenvolvimento na Amazônia Oriental e no Rio de Janeiro. 2010. Tese (Doutorado). Programa de Pós-graduação em Sociologia e Antropologia, Universidade Federal do Rio de Janeiro 0 projeto neoextrativista e a disputa por bens naturais no território: mineração, direitos e contestação social em torno da terra e da água. In: CANUTO, A. N.;LUZ, C. R. e LAZZARIN, F. (Ed.). Conflitos no Campo Brasil 2012. Goiânia: CPT Nacional Brasil, 2013. p.75-87.

SILVA, C. Moradores de Pires fecham a BR-040 pela terceira vez para exigir passarelas. EM, 2013. TARROW, S. 0 poder em movimento: movimentos sociais e confronto político. Petrópolis: Vozes, 2009.

TILLY, C.; TARROW, S. Contentious Politics. London: Paradigm Publishers, 2007. 224 p.

TJMG. Diário do Judiciário. Interdito Proibitório, 00064 - 0048578.53.2010.8.13.01 80. Disponível em: <http://ftp.tjmg.jus.br/juridico/diario/index.jsp?dia=1106\& completa=interior\%7C0180>. Acesso em: 26 nov. 2014.

VAINER, C. B. Grandes projetos e organização territorial: os avatares do planejamento regional. In: MARGULIS, S. (Ed.). Meio ambiente: aspectos técnicos e econômicos. Rio de Janeiro: IPEA, v. 2, 1989.

VALOR ECONÔMICO. Namisa inicia plano de investimento de R \$ 4 bi. Revista Ferroviária, 2009.

WEBER, M. Economia e Sociedade: fundamentos da sociologia compreensiva. Brasília: EdUnB, 2000.

Ensaios sobre a Teoria das Ciências Sociais. São Paulo: Ed. Moraes, 2003.

WILSON, J. D. Governing Global Production: Resource Networks in the Asia-Pacific Steel Industry. London: Palgrave Macmillan, 2013. 
RESUMO

0 trabalho discute as relações entre economia, política e sociedade a partir da abordagem weberiana dos fenômenos socioeconômicos. Como estudo de caso, apresenta as estratégias empresariais e estatais promotoras de desenvolvimento econômico, assim como as formas reativas postas em prática por agentes sociais diversificados no município de Congonhas (MG), onde opera a Companhia Siderúrgica Nacional S.A. (CSN). Primeiramente, enfoca a ação econômica derivada da capacidade transformadora de grandes projetos de investimento, analisando a holding CSN e a expansão de suas atividades mineradoras de ferro como elemento essencial de sua estratégia corporativa. Em segundo lugar, analisa a emergência de agentes e práticas sociais operando em um gradiente de contestação social, potencialmente conducente ao confronto político. 0 trabalho demonstra a interação complexa entre agentes e fenômenos socioeconômicos, enfatizando o enraizamento das estratégias corporativa e de desenvolvimento econômico e a dimensão economicamente relevante da contestação social.

\section{PALAVRAS-CHAVE}

Estratégia corporativa. Ação economicamente relevante. Contestação social. CSN. Mineração.

\section{ABSTRACT}

In this paper, I discuss the relations between economy, politics and society based on the Weberian approach towards socioeconomic prenomena. As a case study, I present the development-oriented, corporate and public strategies, as well as the reactive forms performed by diversified social actors in Congonhas, Minas Gerais, Brazil. The city hosts the Companhia Siderúrgica Nacional SA (CSN) iron ore mining operations. Firstly, I focus on the economic action emanated from large investment projects. Accordingly, I analyse the company profile, for which expanding the iron ore business turns to be an essential element in its corporate strategy. Secondly, I discuss the emergence of actors and practices which work along a gradient of social contestation, potentially conducive to contentious politics. In the paper, I demonstrate the complex interactions between socioeconomic actors and phenomena, highlighting the embeddedness of corporate and economic development strategies and the economically relevant dimension of social contestation.

\section{KEYWORDS}

Corporate strategy. Economically relevant action. Social contestation. CSN. Mining. 